\title{
CORPORATE COMMUNICATION UNITS' FUNCTIONS IN STRATEGIC PLANNING: CASE OF KAYSERI'S TOP INDUSTRIAL COMPANIES
}

\author{
H. Nur GORKEMLI \\ Selcuk University, Turkey \\ ngorkemli@selcuk.edu.tr \\ Betul CETINKAYA \\ Selcuk University, Turkey \\ ruzbet@hotmail.com
}

\begin{abstract}
Strategic plans, which cover a wide range of processes such as including analyzing inner and outer environment, determining objectives, planning, implementing and evaluating, have been used as a managerial tool for organizations since 1960s. Under heavy competitive environment and political/economic uncertainties of countries, it is possible to say that it becomes a necessity to have strategic plans in order to overcome possible obstacles, set competitive advantage and achieve corporate goals. Due to their crucial position with the managerial team, corporate communication departments of organizations play a key role during implementation of strategic plans in various phases. Aim of this study is to understand the role of corporate communication units during different stages of strategic plans in top level companies. In this study, after giving brief information about strategic planning and its advantages to organizations, role of corporate communication departments in strategic management process will be discussed. Later, strategic planning practices of city of Kayseri's companies that were in the top 1000 in Istanbul Chamber of Industry list in 2015 will be focused in terms of corporate communication axis. Only 16 companies accepted to participate in the study although 28 companies existed in the list. Study showed that besides its various benefits, companies found strategic planning as a bureaucratic and time-demanding activity. Most of the companies didn't share their strategic plans in their corporate web-sites. Meetings and e-mails were the most popular tools while communicating shareholders in every stage of plans. Majority of the companies had crisis management, social responsibility and corporate reputation strategies in their plans; however, only a small group had sponsorship strategies.
\end{abstract}

Keywords: strategic plans, strategic management, corporate communication, industrial establishments, Kayseri

\section{KURUMSAL İLETIŞIM BİRIMLERININ STRATEJIKK PLANLAMA SÜRECINDEKİ İSLEVLERİ: KAYSERİ ÖRNEĞİ}

\section{ÖZ}

Stratejik planlar 1960'lardan günümüze işletmelere rekabet avantajı sağlamaları ve hedeflerine ulaşmaları için önemli bir yönetim aracı olarak kullanılmaktadır. İç ve dış çevre analizinden hedeflerin belirlenmesine, planın uygulamasından değerlendirilmesine kadar pek çok farklı aşamaları kapsayan stratejik planlar, belirsizliklerin giderilmesinde, iş dünyasında karşılaşılabilecek zorlukların aşılmasında ve hedeflere ulaşılmasında önemli avantajlar sağlamaktadır. Yönetim kadrosunun hemen yanında yer alan kurumsal iletişim birimleri, pek çok farklı ve kapsamlı süreçleri içinde barındıran stratejik planların hemen her safhasında anahtar bir rol üstlenmektedir. Bu çalışmanın amacı kurumsallaşmış firmalarda kurumsal iletişim bölümlerinin stratejik planlamanın farklı evrelerindeki rolünü araştırmak ve değerlendirmektir. Çalışmada önce stratejik planlar, organizasyona sağladıkları avantajlar ve süreçteki zorluklar hakkında kısa bilgiler verildikten sonra kurumsal iletişim birimlerinin stratejik yönetim süreci içerisindeki rolüne değinilecektir. Çalışmanın araştırma bölümünde ise 
İstanbul Sanayi Odası'nın (İSO) 2015 yılı Türkiye'nin ilk 1000 sanayi kuruluşu listesinde yer alan ve Kayseri'de faaliyet gösteren firmaların stratejik plan uygulamaları, kurumsal iletişim birimlerinin faaliyetleri ekseninde incelenecektir. Bu kapsamda listede yer alan 28 firmanın 16'sı çalışmada yer almayı kabul etmiştir. Çalışma sonuçları firmaların stratejik planlamanın pek çok yararı olduğuna inandıklarını ancak bununla beraber sürecin çok fazla bürokratik detay ve zaman isteyen faaliyetleri içerdiğini düşündüklerini ortaya koymuştur. Paydaşları farklı evrelerde bilgilendirirken kullanılan en yaygın araçların toplantı ve e-postalar olduğu görülmüştür. Firmaların büyük bir kısmı stratejik planlarını kurumsal web sitelerinde paylaşmamaktadır. Stratejik plan içerisinde yer alan kurumsal iletiştim faaliyetleri incelendiğinde şirketlerin çoğunun kriz yönetimi, kurumsal sosyal sorumluluk projeleri ve itibar yönetimi stratejilerinin olduğu ancak çok azında sponsorluk stratejisine yer verildiği görülmüştür.

Anahtar Kelimeler: stratejik plan, stratejik yönetim, kurumsal iletişim, sanayi kuruluşları, Kayseri

\section{INTRODUCTION}

Throughout the history, strategies have been an inseparable element for human beings in their struggle for existence, and as societies grew and conflicts aroused between different groups, strategies were mainly used for military purposes (Shahin, 2011: 13). Strategic plans, which was firstly implemented by private sector in 1960s and started to be used by public sector within 20 years (Gurer, 2006:93), has been accepted by organizations as an important managerial tool to overcome obstacles and achieve goals in highly demanding and competitive environment. From various definitions in the literature, Berry (1994:323) defined strategic planning as "a disciplined effort to produce fundamental decisions and actions that define what an organizations is, what it does and why it does it." With strategic plans, current mission and environmental conditions are brought together to guide future decisions of organizations (Greene et al, 1985:536). It is a process of identifying a route map by selecting the most suitable alternative that emerged after various stages of analyses. From the beginning to the implementation stages of strategic planning, it requires comprehensive and timedemanding activities including lots of bureaucratic works, powerful leadership actions and effective communication practices between various units and stakeholders. Since it is recognized as an important tool to reach organizational medium and long term goals, it is being widely used by many organizations in both public and private sectors despite of its complex structure.

\section{STRATEGIC PLANS AND THEIR BENEFITS TO ORGANIZATIONS}

Strategic plans differ from other plans in various ways. First of all it is a long-run plan when compared with others; therefore they provide a guideline that defines boundaries of other short-run plans of the organization. Moreover, strategic plans have a more complex structure since their scope, flow and process cover lots of data and information. Furthermore, they are proactive whereas short term plans can be reactive for some unexpected developments (Gurer, 2006: 98).

Strategic plans are formulated to answer these three questions:

$\begin{array}{ll}- & \text { Where are we now? } \\ \text { - } & \text { Where do we want to go? } \\ \text { - } & \text { How can we get there? }\end{array}$

Strategic plans involve comprehensive studies in all planning, implementation and evaluation phases. Main work can be summarized in seven steps: (1) defining current situation (2) evaluation of inner and outer environment, (3) formulation of new mission, (4) transferring new mission to strategic goals, (5) formulating strategies and routes for action (6) implementing and (7) evaluating (Gadiesh and Gilbert, 1998:139-147).

Strategic plans bring various benefits that can be addressed in two groups as financial and nonfinancial (Fred, 2011: 16-19). For financial benefits, a visible improvement in sales, profitability and productivity is expected due proactive studies during the preparation of strategic plans. All economic conjuncture, situations of competitors, technological developments, etc. are taken into consideration while preparing the plan and it prepares companies for fluctuations and minimizes all sources of 
financial risks. As for non-financial benefits, strategic management processes encourage organizations to interact with different departments, managers and employees, and provide more participative and democratic working environment, and this bring order, discipline and confidence to the organization. This interactive environment contributes organization's corporate culture formation. With strategic plan, the organization improves the ability to anticipate and prevent the problem, take faster and more accurate decisions and increases employee satisfaction and motivation.

Besides it benefits to the organization, strategic plans also bring some difficulties with its comprehensive process structure. Some of the prominent difficulties can be listed as follows: doing strategic plan only for presentation to external inspection bodies, being very busy with existing problems instead of plan, seeing the plan as an unnecessary bureaucratic work, being too formal and strict in planning process, managerial team's conflicting behaviors with the plan and inability of solving coordination, cooperation, motivation, participation and reluctance problems. And reluctance problems can be caused by several reasons such as lack of experience with strategic plans, having some doubts with the plan, additional costs, additional efforts to carry on, previous unsuccessful experiences, fear of uncertainty, fear of failure and seeing plan as a waste of time (Fred, 2011:16-19).

Establishing a continuous and transparent communication is necessary for achievement of a successful strategic plan. The obstacles can be overcome by interactive, participative, democratic, ethic, dynamic, innovative and cooperative approaches in communication. At this stage, corporate communication departments of organizations play crucial role with its hierarchic place beside and under top managers.

\section{ROLE OF CORPORATE COMMUNICATION IN STRATEGIC PLANNING PROCESS}

Corporate communication, which undertakes all kinds of communication activities related to the organization, aims at contributing corporate's long term reputation by providing harmonious, cooperative, democratic and consistent communication between internal and external target groups. According to Solmaz (2007:28), corporate communication covers all communication activities within organization such as image shaping, contributing changes in organization, building institutional culture, developing media and investor relations, determining general communication policies and providing leadership. The corporate communication units provide creative and persuasive solutions for achieving long and short-term goals of organizations, as well as contributing to develop strategies against internal and external crises (Uludag, 2008:101-102). Crises are special cases that threaten existence and future of organizations and should be immediately reacted (Fidan and Gulsunler, 2003: 466). With all these key functions, it plays a crucial role in strategic management process.

During planning process, corporate communication units should act with a communication strategy consistent with company's strategies. It is expected from corporate communication units to engage organization's leaders as role models within strategic management bring together leaders, managers and employees and manage a communication strategy for the execution of the process (Steyn, 2004:168-183). Moreover a healthy communication should be established with external stakeholders during the execution of the plan.

As it is seen, strategic management process requires continuous interaction between various stakeholders from inside and outside the organization in all phases. This interaction can be achieved with a strong communication strategy that synthesizes the data obtained from internal and external environment in an adaptive and interpretive way instead of concrete and linear approaches. After that, priorities are determined and strategic communication plan is created. Finally actions are taken for external and internal stake holders like media, investors, employees and government (Steyn, 2004:168 $-183)$.

Since strategic management is not a clear and step by step linear process, it requires a constant interaction with stakeholders (Wells, 1996). During this interaction corporate communication units need to express the necessity of the plan to employees. Topics such as what change is needed, why change is needed, what troubles may arise if the plan is not implemented, what might be the case, how employees can contribute to the plan, if the plan is implemented successfully what benefits will be 
there for company and employees should be conveyed and stakeholders support should be provided. There may be also some resistance from employees to the plan, so interpretive, persuasive and adaptable approaches can be applied.

During application of strategic management process corporate communication units focuses on four important areas (Ural, 2006:23):

- Social stakeholder relations integration (includes relations of different parts of the society)

- Management function integration (covers integration to different managerial functions of organizations like marketing, finance, accounting, human resources, etc.)

- Institutional structure integration (includes integration to structural changes of the organization)

- $\quad$ Social integration (covers integration with society via various activities like social responsibility projects)

The corporate communications team can reach their target audience with their written, verbal and technological communication tools. Internal communication can be realized by written means such as brochures, posters, newsletters, and letters. Meetings, sessions and orientation programs are among the verbal communication tools that are effective in sharing and executing the plan successfully. Videotape and teleconference are communication tools that will help the remote target group to reach the message effectively and e-mails will help to convey the plan and process expeditiously (Wells, 1996: 30-32).

\section{KAYSERI'S TOP LEVEL COMPANIES' CORPORATE COMMUNICATION ACTIVITIES DURING STRATEGIC MANAGEMENT}

Istanbul Chamber of Industry (ICI) releases top 1000 industrial enterprises survey in Turkey annually. This study was performed according to 2015 data of ICI and enterprises, which were located in Kayseri and listed in ICI top 1000 industrial enterprise release, were examined in terms of corporate communication activities during strategic management process.

\section{Aim, Scope and Methodology}

The aim of the study is to investigate corporate communication activities of top level companies during strategic planning process. Within this perspective, city of Kayseri's top level industrial companies that were listed among the top industrial companies list of ICI 2015 selected as the sample. The reason for selecting Kayseri's companies is that Kayseri is among the top industrialized cities of Turkey. According to ICI 2015 data, Kayseri ranked in seventh industrialized place over 81 cities of Turkey with its industrial establishments listed in ICI top 500 lists (Paraliman1, 2016). Moreover, Kayseri can be accepted as a good sample since it can represent central Anatolian cities' social and economic structure. Kayseri was represented with its 28 industrial establishments in ICI top 1000 list of the year 2015 (ISO500, 2016). A survey was applied to those establishments through face to face meeting with their representatives (mainly mid-level managers, directors, board members and other responsible persons). Survey questions consisted of three main parts. Eight questions in the first section were aimed at revealing the institution's demographic and institutional characteristics. Corporate communication activities during strategic planning were examined with 20 questions in the second part. Finally, 12 questions in the third part revealed views and perspectives on strategic management experience of the organizations in terms of corporate communication. Questionnaires were pretested on 5 of the sample and necessary changes were done accordingly, and actual survey was performed afterwards. Although all the companies were contacted, only 16 of them accepted to participate in the study. Questionnaires were filled via face to face negotiations with the companies' administrators. Data were analyzed by using SPSS program with descriptive analysis.

\section{Demographical and Corporate Features Findings}

Totally eight questions were asked in the first part of the survey to reveal demographic and corporate features of the companies. As it is seen in Table 1 below, among 16 companies, which were listed in ICI 1000 list, 6 were occupied with bedding and furniture sector, 3 of them were functioning in cable, 
wire and metal sector and 2 of them were operating in textile sector. Other sectors that took part in our study with one company were iron and steel, food, energy, household appliances and polyurethane foam. 5 of the companies were operating less than 15 years and again 5 of them were functioning between 16 and 30 years. 3 companies had a past of 31-45 years and there were also 3 companies operating more than 46 years. When number of employees were analyzed, 5 had 100-500, 4 had 501100,3 had 1001-1500 and 3 had 1501-2000 employees. Only one company had employees in 25003000 range. All the companies under the study had strategic plan experience in different levels, 87,5\% had ongoing strategic plan (they were in the planning stage) and $12,5 \%$ of the companies' strategic plan was in implementation stage. $81 \%$ had previous strategic plan experience and $19 \%$ had no strategic plan in previous years. Mainly mid-level administrators answered the questionnaire. $25 \%$ of the respondents were top level administrators like board member, general manager and vice-general manager, whereas $75 \%$ of the respondents were directors of various units (Table 1).

Table 1. Demographic and Corporate Features

\begin{tabular}{|c|c|c|c|c|c|}
\hline Sectors & Freq. & $\%$ & Person Answered the Questionnaire & Freq & $\%$ \\
\hline$\overline{\text { Bedding and Furniture }}$ & 6 & 38 & Director of Factory & 4 & 25 \\
\hline Iron and Steel & 1 & 6 & Director Planning Unit & 4 & 25 \\
\hline Food & 1 & 6 & Vice General Manager & 2 & 12,5 \\
\hline Energy & 1 & 6 & Board Member & 1 & 6.25 \\
\hline Textile & 2 & 13 & General Manager & 1 & 6.25 \\
\hline Household Appliances & 1 & 6 & Director of R\&D Unit & 1 & 6.25 \\
\hline Polyurethane Foam & 1 & 6 & Director of Quality Management Unit & 1 & 6.25 \\
\hline Cable, Wire and Metal & 3 & 19 & Director of Human Resources Unit & 1 & 6.25 \\
\hline TOTAL & 16 & 100 & Director of Budget Unit & 1 & 6.25 \\
\hline Number of Employees & Freq. & $\%$ & TOTAL & 16 & 100 \\
\hline $100-500$ & 5 & 31 & $\begin{array}{l}\text { Existence of Strategic Plan in Previous } \\
\text { Years? }\end{array}$ & $\begin{array}{l}\text { Fre } \\
\text { q. }\end{array}$ & $\%$ \\
\hline $501-1000$ & 4 & 25 & Yes & 13 & 81 \\
\hline $1001-1500$ & 3 & 19 & No & 3 & 19 \\
\hline $1501-2000$ & 3 & 19 & TOTAL & 16 & 100 \\
\hline $2500-3000$ & 1 & 6 & Existence of Strategic Plan? & $\begin{array}{c}\text { Fre } \\
\text { q. }\end{array}$ & $\%$ \\
\hline TOTAL & 16 & 100 & Yes & 14 & 87.5 \\
\hline Establishment (Years) & Freq. & $\%$ & Being done & 2 & 12.5 \\
\hline Less than 15 & 5 & 31 & TOTAL & 16 & 100 \\
\hline $16-30$ & 5 & 31 & & & \\
\hline $31-45$ & 3 & 19 & & & \\
\hline 46 years and above & 3 & 19 & & & \\
\hline TOTAL & 16 & 100 & & & \\
\hline
\end{tabular}

\section{Findings on Tools for Communication used by Corporate Communication Units during Strategic Plan}

Corporate communication units play important role while providing coordination of different units in various stages of strategic plans. In the questionnaire, respondents answered the means of communication that corporate communication unit used during strategic plans. Answers were organized in three main stages: during planning stage, during implementation stage and during evaluation stage. It was seen that in all stages, meetings and the e-mails were the most popular communication tools. During planning stage all the companies conducted informative meetings, $\% 93.8$ used informative e-mails to stakeholders and $62.5 \%$ organized seminars. Orientation meetings and videos followed these activities with the rates $37.5 \%$ and $31.2 \%$ respectively. Only $25 \%$ had bulletins during this stage. During implementation stage, meetings and the e-mails had the highest 
shares as $87.5 \%$ and $81.2 \%$ respectively. $68.8 \%$ of companies held seminars, which had a higher rate than previous stage. Orientation meetings had $37.5 \%$ in implementation stage. When evaluation stage was examined, it was seen that meetings and e-mails had higher rate than implementation stage and had lower rate than the planning stage with $93.8 \%$ and $87.5 \%$. Seminars followed these tools with a rate of $37.5 \%$. It was seen that posters, brochures and videoconferences were the least preferred communication tools in all three stages of strategic plans (Table 2).

Table 2. Communication Tools used for Strategic Plans

\begin{tabular}{lcccccccccccc}
\hline & \multicolumn{1}{c}{ During Planning Stage } & \multicolumn{4}{c}{$\begin{array}{c}\text { During Implementation } \\
\text { Stage }\end{array}$} & \multicolumn{4}{c}{$\begin{array}{c}\text { During Evaluation } \\
\text { Stage }\end{array}$} \\
\hline Tools & Yes & $\%$ & No & $\mathbf{\%}$ & Yes & $\mathbf{\%}$ & No & \% & Yes & \% & No & \% \\
\hline Brochures & 2 & 12.5 & 14 & 87.5 & 5 & 31.2 & 11 & 68.8 & 2 & 12.5 & 14 & 87.5 \\
Poster & 1 & 6.2 & 15 & 93.8 & 4 & 25 & 12 & 75 & 2 & 12.5 & 14 & 87.5 \\
Bulletin & 4 & 25 & 12 & 75 & 4 & 25 & 12 & 75 & 2 & 12.5 & 14 & 87.5 \\
Meetings & $\mathbf{1 6}$ & $\mathbf{1 0 0}$ & - & - & $\mathbf{1 4}$ & $\mathbf{8 7 . 5}$ & 2 & 12.5 & $\mathbf{1 5}$ & $\mathbf{9 3 . 8}$ & 1 & 6.2 \\
Orientation & $\mathbf{6}$ & $\mathbf{3 7 . 5}$ & $\mathbf{1 0}$ & 62.5 & $\mathbf{6}$ & $\mathbf{3 7 . 5}$ & 10 & 62.5 & $\mathbf{4}$ & $\mathbf{2 5}$ & 12 & 75 \\
Seminars & $\mathbf{1 0}$ & $\mathbf{6 2 . 5}$ & 6 & 37.5 & $\mathbf{1 1}$ & $\mathbf{6 8 . 8}$ & 5 & 31.2 & 6 & 37.5 & 10 & 62.5 \\
E- mail & $\mathbf{1 5}$ & $\mathbf{9 3 . 8}$ & 1 & 6.2 & $\mathbf{1 3}$ & $\mathbf{8 1 . 2}$ & 3 & 18.8 & $\mathbf{1 4}$ & $\mathbf{8 7 . 5}$ & 2 & 12.5 \\
Videos & 5 & 31.2 & 11 & 68.8 & 4 & 25 & 12 & 75 & 4 & 25 & 12 & 75 \\
Videoconference & 3 & 18.8 & 13 & 81.2 & 2 & 12.5 & 14 & 87.5 & 3 & 18.8 & 13 & 81.2 \\
\hline
\end{tabular}

\section{Existence of Strategic Plan on Web Site}

Internet access to strategic plans is an indicator of transparency of managerial activities. Companies were asked whether their strategic plans could be reached in their web sites or not. It was seen that most $(70 \%)$ of the companies didn't share their plans on their websites (Table 3 ).

Table 3. Accessibility of Strategic Plans on Websites of Companies

\begin{tabular}{lll}
\hline Can the Strategic Plan be Reached from Website of the Company? & Freq. & $\mathbf{\%}$ \\
\hline Yes & 5 & 30 \\
No & 11 & 70 \\
\hline Total & $\mathbf{1 6}$ & $\mathbf{1 0 0}$ \\
\hline
\end{tabular}

\section{Findings on the Evaluation of Corporate Communication Activities during Strategic Plans}

In this part of the study companies' participatory, cooperative and adaptive sides were tried to understand. Participatory approach is believed to bring success to strategic plans. Participation should not be limited to executives' contributions but should also take into consideration all-level executives' and employees' thoughts and opinions. The companies were asked to learn whether they adopted this approach or not. It was seen that all the companies except one, adopted participatory approach during strategic plan. Not surprisingly, all of the companies' senior executives contributed to the planning process, whereas 14 out of $16(87.5 \%)$ companies' mid-level executives' contributions were taken into consideration. Only $50 \%$ of companies paid regard to all employees' contributions and suggestions, which could not be an ideal situation. Nevertheless, 15 of 16 companies $(93.8 \%)$ stated that in a case of a problem within the organization, all the employees could contribute to solve it. It was seen that companies accepted opinions and suggestions from employees during some problems but they were not eager to involve all of them into the strategic planning process actively although they stated that they adopted participatory approach in strategic plans. Outside the organization, there are customers 
and general public that should be paid regard during strategic planning process. 13 of 16 companies $(81.2 \%)$ indicated that taking into consideration the general publics' expectations from their company shaped their strategies; however, customers' expectations were much more effective in determining strategies since all of the respondents stated that they shaped strategies according to customers. During the implementation stage, $93.8 \%$ of companies believed that all the employees were conscious and determined, and all of them stated that there were cooperation between all employees and all departments. All the respondents expressed that in order to increase participation, cooperation and solidarity; corporate communication unit provided some activities like seminars and meetings. All of the companies, except one (93.8\%) stated that their strategic plans are adaptive to some unexpected developments (Table 4).

Table 4. Corporate Communication Activities during Strategic Plan

\begin{tabular}{|c|c|c|c|c|c|c|}
\hline \multirow[b]{2}{*}{ During strategic planning....... } & \multicolumn{6}{|c|}{ Frequency } \\
\hline & Yes & $\%$ & No & $\%$ & Hesitant & $\%$ \\
\hline ... a participatory approach is adopted & 15 & 93.8 & 1 & 6.2 & - & - \\
\hline $\begin{array}{l}\text {... senior executives' contributions and suggestions are taken into } \\
\text { consideration }\end{array}$ & 16 & 100 & - & - & - & - \\
\hline $\begin{array}{l}\text {...mid-level executives' contributions and suggestions are taken into } \\
\text { consideration }\end{array}$ & 14 & 87.5 & 2 & 12.5 & - & - \\
\hline $\begin{array}{l}\text {...all the employees' contributions and suggestions are taken into } \\
\text { consideration }\end{array}$ & 8 & 50 & 7 & 43.8 & 1 & 6.2 \\
\hline ....all the staff contribute in solving problems with their suggestions & 15 & 93.8 & 1 & 6.2 & - & - \\
\hline $\begin{array}{l}\text {...general publics' expectations from company are taken into } \\
\text { consideration }\end{array}$ & 13 & 81,2 & 3 & 18.8 & - & - \\
\hline ...customers' expectations from company are taken into consideration & 16 & 100 & - & - & - & - \\
\hline d committed to plan & 15 & 93.8 & 1 & 6.2 & - & - \\
\hline employees. & 16 & 100 & - & - & - & - \\
\hline ...there is enough cooperation between different departments. & 16 & 100 & - & - & - & - \\
\hline $\begin{array}{l}\ldots \text { seminars/meetings are organized to increase participation, } \\
\text { cooperation and solidarity. }\end{array}$ & 16 & 100 & - & - & - & - \\
\hline$\ldots$ an adaptive approach is adopted for unexpected developments & 15 & 93.8 & & 6.2 & - & - \\
\hline
\end{tabular}

\section{Findings on Views about Strategic Plan}

All of the companies believed that strategic plan increased communication within organization; it also provided self-confidence to staff, contributed formation of corporate culture and helped organization to improve their self-knowledge. Moreover, $93.8 \%$ of the respondents agreed that strategic plan provided increased motivation on employees, helped to reach corporate targets, improved ability to foresee possible threats and developed understanding of transparency within organization. Again, majority of respondents $(87.5 \%)$ believed that strategic plans prepared companies to get ready for external fluctuations. Besides all these positive sides, a prominent result of the study was that all respondents were agree that strategic plans demands lots of time and $87.5 \%$ of them claimed that it requires too much bureaucratic work (Table 5).

Table 5. Views on Strategic Planning

\begin{tabular}{|c|c|c|c|c|c|c|}
\hline \multirow{2}{*}{ Strategic Plans....... } & \multicolumn{6}{|c|}{ Frequency } \\
\hline & Yes & $\%$ & No & $\%$ & Hesitant & $\%$ \\
\hline ... increases effective communication between managers & 16 & 100 & - & - & - & - \\
\hline$\ldots$ strengthens dialogue within organization & 16 & 100 & - & - & - & - \\
\hline ... increases staff motivation & 15 & 93.8 & 1 & 6.2 & - & - \\
\hline ...increases self-motivation of employees & 16 & 100 & - & - & - & - \\
\hline ... contributes formation of corporate culture & 16 & 100 & - & - & - & - \\
\hline ... helps to improve self-knowledge & 16 & 100 & - & - & - & - \\
\hline
\end{tabular}


... helps to meet financial goals of organization

... increases transparent understanding of management

... demands lots of time.

... induces too much bureaucratic work

... prepares companies for external fluctuations

gives companies the ability to foresee problems
15

15

16

14

14

15

$\begin{array}{ccc}93.8 & 1 & 6.2 \\ 93.8 & 1 & 6.2 \\ \mathbf{1 0 0} & - & - \\ 87.5 & 2 & 12.5 \\ 87.5 & 1 & 87.5 \\ 93.8 & 1 & 6.2\end{array}$

\section{Findings on Existence of Corporate Communication Strategies}

Questions related to existence of corporate communication activities in strategic plans were asked to companies. It was seen that most of the them had crisis management, social responsibility and corporate reputation strategies in their strategic plans (having the rates of $87.5 \%, 81.2 \%$ and $81.2 \%$ respectively); whereas only $25 \%$ of the firms had sponsorship strategies (Table 6).

\section{Table 6. Existence of Corporate Communication Strategies}

\begin{tabular}{lcccccc}
\hline \multirow{2}{*}{ In our Strategic Plan...... } & \multicolumn{6}{c}{ Frequency } \\
\cline { 2 - 7 } & Yes & $\mathbf{\%}$ & No & $\mathbf{\%}$ & Hesitant & \% \\
\hline ... there are crisis management strategies & 14 & 87.5 & 1 & 6.2 & 1 & 6.2 \\
... there are social responsibility strategies & 13 & 81.2 & 2 & 12.5 & 1 & 6.2 \\
... there are corporate reputation strategies & 13 & 81.2 & 3 & 18.8 & - & - \\
$\ldots$ there are sponsorship strategies & 4 & 25 & 7 & 43.8 & 5 & 31.2 \\
\hline
\end{tabular}

\section{DISCUSSION AND CONCLUSION}

Increased competitive environment brought the necessity of strategic management for companies. With the help of strategic management, organizations enhance their capability to overcome possible threats, see and take the advantage of opportunities by taking into consideration their strengths and weaknesses. With their strategic plans, organizations not only increase their financial benefits, but also develop their organizational, participative and communicative skills. Therefore, many organizations both in private and public sectors apply strategic management to have such benefits.

Of course this comprehensive process requires interactive, participative and dynamic communication among various groups within and outside the organization. In this study we tried to see corporate communication departments' activities during strategic planning process of corporate companies located in Kayseri and placed among top 1000 industrial establishments in Turkey.

Among 28 establishments, which were listed in top 1000 industrial establishments list, 16 of them accepted to participate in the study. Findings of the study are listed below:

- $\quad$ All the companies in the study are operating in manufacturing industry.

- $\quad$ Almost $70 \%$ of firms are operating more than 15 years.

- $\quad 19 \%$ of the companies had no previous strategic plan experience before

- In all stages of strategic plan meetings and the e-mails were the most popular communication tools, whereas posters, brochures and videoconferences were the least preferred ones.

- $\quad$ Only $30 \%$ of the companies shared their strategic plans in their websites.

- $\quad$ All the companies stated that they adopted participatory approach during strategic planning and mostly senior and mid-level executives' contributions were taken into account, whereas only $50 \%$ of them involve employees in all level during the planning process. However, 93.8\% of organizations accept all the employees' contribution when a problem occurs during implementation of planning.

- $\quad$ Customers' expectations were all taken into account in shaping strategic plans and this rate is $81.2 \%$ for considering general public's opinions. 
- $\quad$ All of the firms organized events like seminars and meetings in order to increase participation, cooperation and solidarity.

- $93.8 \%$ of organizations' strategic plans are flexible for some unexpected developments.

- $\quad$ They all believed that strategic plan contributed to increase communication between managers and employees, provided self-confidence to staff, supported to improve selfknowledge of the organizations and contributed to form corporate culture.

With very high percentages, they agreed that strategic plans increased motivation of employees, helped to reach corporate targets, improved ability to foresee possible threats and developed understanding of transparency within organization.

- $\quad$ Together with all positive views of plans, most of the companies complained with the high bureaucratic work and time-demanding activities of strategic plans.

- $\quad$ Companies mostly had corporate communication strategies like crisis management, social responsibility and corporate reputation in their strategic plans; however, only $25 \%$ of them had sponsorship strategies.

It is possible to say that all companies believed in the benefits of strategic plans in financial and nonfinancial ways but they accepted that it was a time and effort demanding activity. Companies mainly involved senior and mid-level executives in all strategic planning stages, and only half of them involve all employees; however, in case of problems, all employees' contributions were accepted. Communication with stakeholders was mainly provided through meetings and e-mails. Although they highly believed in strategic plans' contribution to transparent understanding of management, only $30 \%$ of them shared the plan in their website.

Although companies in the study were aware of the benefits of strategic plans to their companies in terms of financial and human resources aspects, they admitted that this process is highly timedemanding. These obstacles can only be overcome with a strong, adaptive and interpretive strategic communication plans which enable continuous interaction between all the stakeholders from inside and outside the organization during the whole process. The stakeholders should be included in the process with motivating, supportive and persuasive approaches by using various communication tools. With a successful strategic communication plan, it could be said that achieving corporate goals becomes easily and more effectively.

This study examined Kayseri's top level companies' strategic plan experiences, views and obstacles with the context of their corporate communication activities to understand and guide future planning activities. For future studies, the research can be carried to a further comprehensive dimension by extending it to all companies existed in top 500 or 1000 lists. By this way it would be possible to achieve more guiding results to evaluate the existing role of corporate communication departments in strategic planning studies and develop more comprehensive recommendations for successful plans.

\section{REFERENCES}

Berry F. S., (1994). "Innovation in Public Management: The Adoption of Strtaegic Planning”, Public Administration Review, 54 (4), pp: 322-330

Fidan M., Gulsunler M. E., (2003). "Kurum Kimliginde Kriz Yonetiminin Yeri ve Onemi”, Selcuk Universitesi Sosyal Bilimler Enstitusu Dergisi, 10, pp.465-475

Gadiesh O. and Gilbert J. L., (1998). "Profit Pools: A Fresh look at Strategy". Harvard Business Review, 76(3), pp. 139-147

Greene, C.N., Adam, E.A. Jr. and Ebert, R.J., (1985). Management for Effective Performance. Englewood Cliffs, New Jersey: Prentice-Hall.

Gurer, H., (2006). "Stratejik Planlamanin Temelleri ve Türk Kamu Yonetiminde Uygulanmasina Yonelik Oneriler”, Sayistay Dergisi, 63, pp. 91-104.

Shahin B. (2011). Evaluating the Effectiveness of Strategic Planning Within the Middle Eastern Public Sector. Doctoral Thesis in Business Administration. Victoria Graduate School of Business. Victoria 
The Turkish Online Journal of Design, Art and Communication - TOJDAC October 2017 Volume 7 Issue 4

University Melbourne, Australia. $\quad$ http://vuir.vu.edu.au/19416/1/Basel_Shahin.pdf (Accessed on 12.09.2017)

Solmaz B. (2007). Kurumsal İletişim Yönetimi, Konya, Tablet Kitabevi

Steyn B. (2004). "From strategy to corporate communication strategy: A Conceptualisation", Journal of Communication Management, 8(2), pp. 168-183

ISO 500, (2016). Türkiye'nin Birinci 500 Büyük Sanayi Kuruluşu, http://www.iso500.org.tr/iso-500hakkinda/gecmis-yil-verileri/ (Accessed on 01.12.2016)

Paralimanı (2016). Türkiye'nin en büyük 25 sanayi şehri hangisi?,

http://www.paralimani.com/turkiye-nin-en-buyuk-25-sanayi-sehri-hangisi-haberi-58869/ (Accessed on 01.12.2016)

Uludag, A. (2008). "Halkla Ilişkilerde Stratejik Süreç", Halkla İlişkiler, (Editör: Ahmet Kalender ve Mehmet Fidan), Konya: Tablet Yayınlart

Ural, E.G. (2006). Stratejik Halkla Iliskiler Uygulamaları. Istanbul: Birsen Yayınevi.

Wells D. L. (1996). Strategic Management for Senior Leaders: A Handbook for Implementation, Department of the Navy Total Quality Leadership Office http://unpan1.un.org/intradoc/groups/public/documents/aspa/unpan002503.pdf (Accessed on 13.03.2016) 